\title{
SIX UNUSUAL BOATS FROM TELL AWLAD DAWOOD IN THE NILE DELTA
}

\author{
By \\ Ahmed Said Nassef \& Ehab Gamil Abd El-Krim \\ Lecturers at Department of History and Archeology, Faculty of Arts, Benha \\ University, Egypt.
}

\begin{abstract}
Tell Awlad Dawood is a Predynastic and Early Dynastic settlement located in Sharqiya Province. The site is a small Tell. It has been occupied from the beginning of the $4^{\text {th }}$ millennium BC to the Late Period, but its main occupation took place during the Predynastic and Early Dynastic times. The site of Tell Awlad Dawood in the eastern Nile Delta has been the focus of excavation since 1978. Until 1997, the main discoveries made at the site were: some buildings, bowls, platters and vats, ovoid and globular pots, large pots with a wide opening, jars, some lithic industry, and six pottery boats. The current paper is concerned with the study and publication of Six Unusual Boats which were discovered in Tell Awlad Dawood in 1997. The six boats are made of pottery, particularly of Nile Clay, and the used shaping technology is handmade. The research has proved that these boats are dated to Naqada IID2 or the Beginning of Naqada III A-B at the latest from Late Chalcolithic to Proto-Dynastic period (3600- 3300 BC) according to the division of relative chronology of Naqada culture by S. Hendrickx. All the six boats are currently housed in the Grand Egyptian Museum magazine in Cairo.
\end{abstract}

KeYwords: Boats, Tell Awlad Dawood, Naqada III, Protodynastic, Early dynastic, Pottery. 


\section{SIX UNUSUAL BOATS FROM TELL AWLAD DAWOOD IN THE NILE DELTA}

\section{INTRODUCTION}

Tell Awlad Dawood is situated in Sharqiya Province. It is located in the area between «Tell el Yahudeya and Belbeis (20 km south of Belbeis, and $17 \mathrm{~km}$ northeast of Tell el Yahudiya) [FIGURES 1 -3], in the area of the village so-called » El Ghaffarîa «belonging to the town » Mashtûl el Sûq «(ca. $50 \mathrm{~km}$ to the south of Zagazig city) and in front of »El Ghaffarîa » village (ca. $1 \mathrm{~km}$ within the cultivated area). In ancient times, it was geographically located within the boundaries of the $13^{\text {th }}$ nome of Lower Egypt « $\left.h k\right\}^{`} \underline{d}$ » Pf.

This site was discovered in 1978 by the Supreme Council of Antiquities, exposing an important stratigraphic sequence where the earlier levels show affinities with the Lower Egyptian Culture; the upper levels belong to the Naqada III-Early Dynastic Period. The work carried out by the Supreme Council of Antiquities revealed Tell Awlad Dawood as a «key site» for understanding human occupation in the 4 th millennium BC in the Nile Delta.

So far, the available data provided by Excavation reports, made in the site from 1978 to $1997^{1}$, suggest dating Tell Awlad Dawood to the beginning of the early dynastic period coinciding with Naqada III (A-B) in Upper Egypt. The settlement continued during the archaeological period coinciding with Naqada III (C-D) and this period represented the first phase of settlement at this site. Also, many archaeological remains were found in the site like pottery fragments, and some poorly preserved Old Kingdom remains that may have belonged to the dwellings in the site, in addition to an area that included a group of tombs. Therefore, the site dates to different periods, starting from the prehistoric period through the Old Kingdom to the late and Ptolemaic period, indicating the importance of the site.

Certainly, the current shape of the site [FIGURES 4-5] resulted from the plowing operations to prepare the land for cultivation methods that appeared in the period of Naqada III (C), and Naqada III (D), establishing the sedimentary accumulation in the site. Based on the information from the excavations, the site dates back to Naqada III (A) and Naqada III (B) ${ }^{2}$.

\section{Cultural and Religious Significance of Boats}

Boats played a major role in ancient Egyptian society ${ }^{3}$. The boats differed in their shapes and uses. Their fronts took various forms such as papyrus, lotus, and some animals and birds' heads, such as the falcon, the ram, the hedgehog and the baboon ${ }^{4}$.

\footnotetext{
1 SAID 1978 unpublished; HAMED 1982 unpublished; Mahmoud 1989 unpublished; NAGY 1990 unpublished; Tariq 1991/1992 unpublished; IBRAHIM 1993 unpublished; MOHSEN 1997 unpublished; EHAB 1997 under publication.

${ }^{2}$ HENDRICKX referred to that in a discussion about the chronology of Naqada culture in an unpublished research paper presented to the British Museum 1993; HENDRICKX, 1993.

3 VAN DE MOORTEL 2007: 1.

${ }^{4}$ There are many studies about history of the emergence of Egyptian boats, their materials, the names of their hull parts, their types and uses: REISNER 1913; LANDSTRÖM 1970; VINSON 1987; CASSON 1994; VINSON, 1994; CASSON 1995; WARD 2000 a; WARD 2000 b; MCGRAIL 2004; GILBERT 2008; VINSON 2008; VINSON 2013.
} 
The Egyptians constructed various types of boats for various purposes. Some of them were used for transportation and travel purposes. Since the predynastic period, some boats were used for special purposes in religious ceremonies and rituals ${ }^{5}$, and they were also used for hunting since Naqada $\mathrm{II}^{6}$.

The Egyptians knew how to make boats since the predynastic period. This showed through rock drawings and pottery vessels dating back to Naqada I and Naqada II which indicates the skills of the ancient Egyptian on the sea ${ }^{7}$. Its scenes show the shapes of the boats depicted on the white-painted pottery of Naqada I. Among the boat models of this stage are an image of a full-side position boat and another in full horizontal projection.. As for the figure of the boat depicted on the pottery of Naqada II with red drawings, the image of the boat was the central image on the pottery vessels. Boats in that period retained their ancient characteristics that appeared on Naqada I pottery; they were distinguished by depicting two compartments for each boat made of braided plants 8 .

The depiction of boats on pottery vessels during Naqada I and Naqada II indicates the increasing needs of the population in that period for boats and their frequent use for transportation, cargo transport, fishing and marine navigation?.

\section{The Emergence of Pottery Boats}

It is very difficult to determine the earliest date when pottery boats were formed, due to the scarcity of models of boats of the predynastic period, which are few compared to the pictures of boats in the pottery paintings vessels and other rock surfaces. Only twelve examples have been found in tombs of this period so far ${ }^{10}$.

Perhaps the oldest archaeological evidence of the appearance of pottery boats during the Neolithic period comes from Merimde culture, which is a small model of a pottery boat ${ }^{11}$. It is a boat equipped with a flat upper edge that extends towards its high end ${ }^{12}$, and a model of a pottery boat dating back to el-Omari culture was preserved in the Berlin Museum ${ }^{13}$, as well as a model of a boat of burnt mud in the Munich Museum dating to Naqada $\mathrm{II}^{14}$. Three mud boats in the Ashmolean Museum of Artand Archaeology date to the predynastic ${ }^{15}$.

\footnotetext{
${ }^{5}$ BARBARA 1997: 36-48.

${ }^{6}$ GILBERT 1998: 69.

${ }^{7}$ IBRAHIM 1984: 44.

${ }^{8}$ HOSNI 2011: $24 \mathrm{ff}$.

${ }^{9}$ GILBERT 1998: 69.

${ }^{10}$ HOSNI 2011: 27.

${ }^{11}$ ABDEL AZIZ 1992: 96.

12 PETRIE 1933: 4.

${ }^{13}$ GÖTTLICHER 1971: TAF. 7.

${ }^{14}$ HOSNI 2011: 29. FIG. 12.

${ }^{15}$ HOSNI 2011: 29. FIG. 13.
} 


\section{SIX UNUSUAL BOATS FROM TELL AWLAD DAWOOD IN THE NILE DELTA}

\section{Description Of Six BoAts}

According to the Egyptian Survey Expedition plan that started excavation work in the site in 1997 [FIGURE 6] the excavation trench was $15 \times 10 \mathrm{~m}$, and these excavations were carried out in a layered system. The boats were found $5 \mathrm{~m}$ from the eastern side of the trench and $20 \mathrm{~cm}$ from the south side. Next to a large mud-brick wall, (it is suggested that this part of the site was dedicated for burials), where an oval- shaped burial (length: $165 \mathrm{~cm}$, width: $70 \mathrm{~cm}$ ) was found with a poor reserved child body(length: $75 \mathrm{~cm}$ ), and three skulls in poor condition were found $410 \mathrm{~cm}$ from the south side.Thus, the six boats were found in a funerary context, but it is difficult to determinewhen it was used for burial ${ }^{16}$.

In the culture of Lower Egypt, pottery was made from silt clay extracted from the Nile and diluted with mixed mineral materials from sand or hammered stones, and the main raw materials used in industry are local silt from the Nile and marl silt from the desert edges. The pottery discovered at the site of Tell Awlad Dawood was made from the first type -that was used on a large scale-from which the six boats discovered in the site were made. The types of pottery made of clay and lime earth found in Upper Egypt were also recorded in other sites in the Nile Delta, such as Tell el-Farkha, Tell el Iswid and Menshat Abu Omar. But no pits (built of mud-bricks) for boats were discovered in the region of Delta up till now, which were placed with the deceased like these in Upper Egypt. Perhaps this is due to the nature of the earth and the high level of underground water which destroyed the organic materials placed in there, except that, a model of a boat was found made of calcite stone in the form of papyrus in Menshat Abu Omar which was placed in the burial chamber with thedeceased, and two boats of hippopotamus bones were found at Tell el-Farkha' ${ }^{17}$.

\section{The First Boat (GEM. №. 67656)}

A model of a pottery boat with a height of $6 \mathrm{~cm}$., a width of $10.5 \mathrm{~cm}$., and length of 16 $\mathrm{cm}$. It is a small boat with a curved bottom in which the height of the front is equal to the height of the stern. The boat takes a semi-oval shape and only a few decorations remain above the edge which is in the form of an ostrich [FIGURE 7].

\section{The Second Boat (GEM. № . 67657)}

A model of a pottery boat with a height of $8.5 \mathrm{~cm}$., a width of $9 \mathrm{~cm}$., and a length of $23.5 \mathrm{~cm}$. The height of the front which is shaped like the head of an ostrich bird is equal to the stern which takes the shape of the back of an ostrich. The rim is surmounted on all sides by what looks like cylindrical columns, some of which are missing and others have been restored and assembled with traces of ink; it is a small boat with a curved bottom [FIGURE 8].

\footnotetext{
16 MOHSEN 1997.

17 KROEPER 1994: 88.
} 


\section{The Third Boat (GEM. №. 67658)}

A model of a boat made of pottery with a height of $10 \mathrm{~cm}$., a width of $8.5 \mathrm{~cm}$., and a length of $22.5 \mathrm{~cm}$. The height of the front, which takes the shape of the head of a dog with upright ears, is equal to the stern of the boat, which takes the form of a dog's tail raised up, belonging to a breed that the Egyptians call «the Saluki». It is similar to the previous boat, where the rim is surmounted on all sides by what looks like cylindrical columns, some of which are missing, and others have been restored and assembled and there is a fracture in the body of the boat from the middle [FIGURE 9].

\section{The Fourth Boat (GEM. №. 67659)}

A model of a boat made of pottery with a height of $7.5 \mathrm{~cm}$., a width of $12 \mathrm{~cm}$., and a length of $17.5 \mathrm{~cm}$. The front of the boat rises higher than the stern. It is a small boat with a curved bottom that takes a semi-oval shape, with a break in the body of the boat in the middle. The decorations above the edge take the shape of the head of an ostrich bird [FIGURE 10].

\section{The Fifth Boat (GEM. №. 67660)}

A model of a boat made of pottery is similar to the first and fourth boats in terms of the decoration above the edge, as it is in the form of the head of an ostrich bird. The height of the boat is $6 \mathrm{~cm}$, its width is $10 \mathrm{~cm}$., and its length is $16 \mathrm{~cm}$. The bow of the boatis equal to the height of the stern, which takes a semi-oval shape [FIGURE 11].

\section{The Sixth Boat (GEM. №. 67661)}

It is a model of a small boat with a curved bottom made of pottery [FIGURE 12]. The height of the boat is $10.5 \mathrm{~cm}$; its width is $9.5 \mathrm{~cm}$., and its length is $23 \mathrm{~cm}$. The height of the bow takes the shape of a hedgehog's head and is equal to the height of the stern, which takes the form of the back of a hedgehog. This boat resembles the second and third boats in terms of decorative elements that top the edge from all sides. They resemble cylindrical columns, some of which are missing and others are restored and assembled.

\section{COMMENTARY}

As we have seen through the previous description, the set of boat models is made of pottery in 3D (three-dimensions), and provides a complete picture of the shape of the boats. They are six unique design boats, three are in a semi-oval shape (the first, fourth and fifth). Along with their edges, there are decorative shapes in the form of ostrich heads characterized by a long neck; some ostrich heads are missed in some boats. Its thickness and size vary from one boat to another. The two boats (GEM №. 67656) \& (GEM №. 67659) have a very round surfaces, and this type of boat belongs to boats with around bodies ${ }^{18}$.

${ }^{18}$ CASSON 1995: 66. 


\section{SIX UNUSUAL BOATS FROM TELL AWLAD DAWOOD IN THE NILE DELTA}

The details of the boats indicate a high level of craftsmanship, and there are many examples of pottery boats with pottery animals and birds on them ${ }^{19}$.

The motif and method of placing decorative elements on boats along the edges are similar to those found on a boat from the Naqada I discovered in Assiut, and preserved in the Leiden Museum in the Netherlands, Inv. Nr.f 1962 / 12.1, inside is a man in a squatting position [FIGURE 13] ${ }^{20}$.

As for the ostrich bird's association with boats, similar examples have been found in many rock drawings and pottery vessel drawings since the predynastic period. Examples of ostrich birds with boats which were a major artistic element depicted on rock surfaces for an extended time indicate that ostriches were present in the eastern desert. ${ }^{21}$ [FIGURE 14], as in the case of Nubia and even in Western Sahara, these drawings became a major element in pottery drawings ${ }^{22}$ [FIGURE 15].

The depiction of birds as a decorative element is a feature that was common on boats during the predynastic period. The presence of the ostrich as a decorative element on Tell Awlad Dawood boats is similar to the model of a boat preserved in the Brussels Museum E7067. [FIGURE 16] In terms of the representation of ostrich heads as a decorative element on the deck of the boat, the boat made of hippopotamus ivory and dated to Naqada II, and depicted with five falcons ${ }^{23}$. The falcons are looking at the rear of the boat, and four fragments of birds have been restored, the last bird was questioned whether it is actually part of the boat or not. Its material looks different from the rest of the boat, and its thickness is less than the rest of the other four birds. HENDRICKX ${ }^{24}$ believes it is difficult to be a hawk because it is represented by the long neck, contrasting with the other birds shown on the boat.. It is assumed that the fifth bird in the Brussels boat is an ostrich, which is distinguished by its long neck ${ }^{25}$. Therefore, there tends to be a connection between the depiction of decorative elements in the form of ostrich heads on the boats of Tell Awlad Dawood and the Brussels boat and this topic remains debatable.

Other examples illustrate our hypothesis about the bird depicted on the boats of Tell Awlad Dawood. The birds on the boats closely resemble the shape of an ostrich, which was represented on a comb decorated with an ostrich shape made of bones and dated to the late Naqada I period - Naqada II period. It is found in the Metropolitan Museum ${ }^{26}$ [FIGURE 17].

\footnotetext{
${ }_{19}^{19}$ Abydos, AM E.2813; Helwan; Hu tomb B182, UC.10805; Minshat Abu Omar, Cairo Museum; Naqada, AM 1895.622; Naqada; Tell el-Farkha; unknown, München ÄS 7182; unknown, Berlin 13834; unknown, UC.16276; unknown, Swansea W924 HeNDRICKX 2008: 373, Note. 3; Tell Ibrahim Awad: SHERKOVA 2002: 165-178; SHERKOVA 2003: 504-508.

${ }^{20}$ SEIPEL 1989: 43, N.8.

${ }^{21}$ FRANCIS 2012: 134.

22 WINKLER 1938: 26, 35; ENGELMAYER 1965; HOFMANN 1979: 243-8.

23 VANHULLE 2018: 176.

${ }^{24}$ HENDRICKX 2008: PL. I.1.

${ }^{25}$ HALA 2015: 108.

${ }^{26}$ VENICE 2018: 15.
} 
The same decoration was depicted in the form of the head of an ostrich bird on the ostrich palette or Manchester palette №. 5476, which dates back to Naqada II. On the upper part of the first face of the palette, a man appears, showing the features of his hands and carrying a stick in his right hand. In front of the man there are three ostrich birds that he leads or hunts. The edge of one of the upper parts of the palette is shaped like a bird that resembles the head of an ostrich represented on the palette, and it is the same shape as the heads found on the boats of Tell Awlad Dawood ${ }^{27}$ [FIGURE 18].

The previous discussion shows that the representation of ostriches - whether on pottery or on the surfaces of rocks or even on models of boats - was a common feature in the predynastic period, due to the important role that ostriches played in that period. From the mundane side, it had great economic importance through the use of ostrich eggs $^{28}$ sometimes as special containers used to feed children, and they were placed in the graves, as well as the use of ostrich eggshell fragments (small pieces) in making various shapes of beads used in making necklaces and continued use of them throughout the historical ages ${ }^{29}$.

As for the role of the ostrich from the religious point of view, there were religious references to it during prehistoric and historical eras, where the ostrich feather represented a sacred symbol ${ }^{30}$. Then it continued behind the front of the sun boat, and it was depicting a row of feathers that numbered up to nine, and that number varied from one boat to another.

Selim Hassan believed that the ostrich feather appeared at the beginning in chapter of the boat with the the pyramid texts ${ }^{31}$. Ostrich eggs were also associated with divine birth and theories of the creation of the universe. It was also believed that eggs breathe life inside their shell and could bring air to the dead. During the Egyptian dynasties the manifestations of egg revival spread, and this explains the abundance of eggshells or fragments in various tombs. They are believed to be symbols of eternal life and rebirth ${ }^{32}$.

Through the above information, the economic importance of the ostrich, its religious role, and its representation on pottery vessels, rocks, palettes, and in boat models, suggest that the decorative elements depicted on the boats of Tell Awlad Dawood (first, fourth and fifth) are mostly ostrich heads.

Concerning the other three boats (the second - third and sixth), the rim is surmounted by decorative elements on all sides that resemble columns with a cylindrical shape. These cylindrical shapes may represent the stems of papyrus. Boats were initially made from bundles of papyrus or cans and reeds, so the papyrus stems and flowers were represented. Some columns splayed from the top represent the mellow papyrus flower [FIGURE 19].

\footnotetext{
27 VANDIER 1952: 572, FIG. 379.

${ }^{28}$ DINA 2010.

${ }^{29}$ VENICE 2018: 11.

${ }^{30}$ AlAADDIN 2000: 9.

31 HALA 2015: 139.

32 VENICE 2018: 11.
} 


\section{SIX UNUSUAL BOATS FROM TELL AWLAD DAWOOD IN THE NILE DELTA}

These columns were placed next to each other to form a wall on the edge on all sides. The ancient Egyptian used to walk between the papyrus sticks in the Nile, riding his boat, and the papyrus stems surrounded it on each side as if it were a wall surrounding him in the Nile, so he represented this when designing the model of his boat. Therefore, depicting the decorative elements that take the form of columns on the three boats is a method by which the ancient Egyptian used to sail on the Nile surrounded by papyrus plants like walls, and he depicted that in the model of his boat. Thus, the decorative elements on the three boats in the form of columns explain how the ancient Egyptian wanted to express that he is inside his boat with its columns, as if he was in the middle of the Nile, surrounded by the floweringpapyrus stems.

With regard to the front and rear of the three boats, their shapes differed, so the front of the second boat [GEM. №. 67657] [FIGURE 8] takes the shape of ostrich's head bird [FIGURE 20] and the stern takes the shape of the rear of an ostrich, and we have previously referred to the artistic significance of depicting the front and the stern of the boats is like this.

The third boat's [GEM. №. 67658] [FIGURE 9] front takes the shape of a dog's head with upright ears and the stern takes the form of a dog's tail raised up. It refers to a kind of $\operatorname{dog}$ called by the Egyptians tsm [FIGURE21] and we see the determinative resembling the shape taken by the front of the boat. The dog is one of the animals that the ancient Egyptians had been interested in since ancient times, as a cemetery was found in Heliopolis dating back to the predynastic life with human burials and burials of $\operatorname{dogs}^{35}$. The connection of this shape of the dog with boats appeared in a picture depicted on a plate dating back to Naqada I, in the Egyptian museum CG 58677 [FIGURE 22]. The dog is depicted in a view above a boat ${ }^{36}$. The bow took the shape of a dog due to its role in hunting and guarding. It connected with many to many deities, and parts of this animal were associated with boats during later ages ${ }^{37}$.

As for the sixth boat of Tell Awlad Dawood [GEM №. 67661] [FIGURE 12], which took the shape of the head of a hedgehog ${ }^{38}$ [FIGURE 23].and the stern took the shape of the rear of the hedgehog, the oldest depiction of a hedgehog on a pottery vessel dates back to the Naqada I. As it appeared on many archaeological models ${ }^{39}$, including the discovered boat in Tell Ibrahim Awad [FIGURE 24], where the hedgehog was depicted on the bow. The boat was among some models placed as foundation deposits of the temples ${ }^{40}$. The head of the hedgehog at the bow had a major role in banishing evil in addition to its magical role in protecting the ship's passengers, and it was then associated with the sunand birth ${ }^{41}$.

\footnotetext{
${ }^{33}$ GADINER 1994: 602, sign list E 14.

34 REISNER 1936: 97-99.

35 SAMAR 2019: 90.

${ }^{36}$ HALA 2015: 10.

37 HALA 2015: 11-15.

38 AYMAN 2010: 165-197.

${ }^{39}$ HALA 2015: 58-59.

${ }^{40}$ VAN HAARLEM, 1996: 197-198; VAN HAARLEM 2014: PL.11.

${ }^{41}$ HALA 2015: 62-65.

DOI: $10.21608 /$ JGUAA2.2021.52837.1041. 


\section{BOATS OF TELL AWLAD DAWOOD (USE OF)}

The uses and functions of boats varied during the predynastic period, in addition to their usage for transportation and fishing. Some boats were designated for burial within the funerary equipment. Models of small boats were found in the cemeteries of that period to be present with the dead in their afterlife. Thus, some boats were necessary for the dead on their journey to the other world. As appeared in the late predynastic ceremonial boats used in religious ceremonies ${ }^{42}$, as well as the use of some boat models as amulets, such as the one discovered in Tell El-Farkha ${ }^{43}$, and some boat models were placed as foundation deposits of the temples, such as the boat discovered in Tell Ibrahim Awad ${ }^{44}$.

We suggest that the models of the boats of Tell Awlad Dawood were used as basic deposits, like the boat discovered at Tell Ibrahim Awad, and we exclude that these boats were for funeral purposes. As in the Delta region where Tell Awlad Dawood is located, boats made of mud or wood were not found; this is due to the soil nature in the Nile Delta which is affected by the high level of groundwater, which destructs the organic materials. This type of funeral boat was found in Upper Egypt. The model of the only boats discovered in the Nile Delta, whether in Tell El-Farkha used as amulets or in Tell Ibrahim Awad as foundation deposits of the temples. It confirms our assumption about the use of the boats of the Tell Awlad Dawood as foundation deposits of the temples, and this assumption explains the importance of the site from the religious point of view. The presence of a foundation deposit of the temple at the site suggests that the discovering area of Tell Awlad Dawood may include a temple such as the temple of Tell Ibrahim 'Awad, and discussions about the proposal are still open.

No pits (built of mud-bricks) for boats were discovered in the region of Delta up till now, which were placed with the deceased like these ones in Upper Egypt, and perhaps this is due to the nature of the earth and the high level of underground water which destroyed the organic materials placed in there, except that, a model of a boat was found made of calcite stone in the form of papyrus in Menshat Abu Omar which was placed in the burial chamber with the deceased. Two boats of hippopotamus bones were found at Tell El-Farkha. The absence of pottery boats -used in the burialsconfirms our hypothesis that the boats of Tell Awlad Dawood were foundation deposits, and they were not used during the burial process as funeral boats to be placed with the deceased.

\footnotetext{
42 HOSNI 2011: 36.

43 CiAŁOWICZ 2009: 437. FiG. 28.

44 VAN HAARLEM, 1996: 197-198; VAN HAARLEM 2014: PL.11.
} 


\section{SIX UNUSUAL BOATS FROM TELL AWLAD DAWOOD IN THE NILE DELTA}

\section{V.DATING}

According to the division of relative chronology of Naqada culture by S. Hendrickx we suggest that the boats of Tell Awlad Dawood are dated to Naqada IID2, or Beginning of Naqada III A-B at the latest, from Late Chalcolithic to Proto-Dynastic period [3600- $3300 \mathrm{BC}$ ] according to the following shreds of evidencemost of which have been mentioned in the context of the study:

- Many boats were depicted on pottery vessels in the Naqada II. Rather, it was the central image of pottery vessels, and on it and around it the rest of the human, animal, plant, geometrical and other decorative elements were distributed ${ }^{45}$. This indicated the increasing need of the people of this period for boats and their frequent use of them. ${ }^{46}$

- Ostrich birds as decorative elements appeared in the boat models of the Tell Awlad Dawood. As mentioned earlier, many examples of other boats appeared in Naqada II.

- These boats cannot be dated to the Early Dynastic Period, because most boats most boats of this period were distinguished by a distinctive technical mark, showing height stern, ${ }^{47}$ an element that was not available in the boats of the Tell Awlad Dawood. The boats of the Early Dynastic Period differed with the three-dimensional models of the boats of Tell Awlad Dawood in terms of function. In the Early Dynastic Period, the desire of the owners of the graves to have at their disposal real means of transportation [not models like the boats of Tell AwladDawood] and effective in the kingdom of the dead, so that the deceased could move freely on the waterways of the lower world, and he will only be able to do that by owning a real boat (not a model) for the other world, and perhaps this was just an imitation of the royal habit, which has been proven since The period of King «Hor- Aha» ${ }^{48}$.

- Generally, the boats were hand-made. The surface treatments observed were those commonly documented for the Naqada III period in the Nile Delta at least.

\section{CONCLUSIONS}

Tell Awlad Dawood appears as a very important site. Like the neighboring sites of Tell el Farkha, Tell Ibrahim Awad and Buto. Tell Awlad Dawood constitutes a fundamental element to get a better understanding of the predynastic period in Egypt and the emergence of the State.

The excavation work at Tell Awlad Dawood was limited to some Egyptian missions that worked on the site for several seasons.. Finding any fixed or movable antiquities on the site of Tell Awlad Dawood, except for some pottery shards and six models of boats made it difficult to date them.

\footnotetext{
${ }^{45}$ HOSNI 2011: 25.

46 OSAMA 2016: 6.

47 OSAMA 2016: 10.

48 RADWAN 2008: $561 \mathrm{ff}$.
} 
This paper calls for interest in conducting more scientific excavations to clarify the religious, historical and cultural importance of this site.

The boat was the most important technological achievement of human history; the boats of Tell Awlad Dawood are unparalleled in design and decoration.

These boat models from the predynastic period are considered to be little compared with the pictures of the boats in pottery paintings and rock surfaces from the same period. The importance of these model boats comes despite their small size, in that they show the three dimensions of boats, a characteristic that cannot be known through the drawings found on pottery and rock images.

The way and shape of the industry indicate that we are dealing with boats made of pottery and not pottery vessels or a curved body similar to tubes found in tombs of the predynastic $^{49}$.

The study was able to identify the rare decorative elements above the edge of the boats as previously mentioned in the technical study of these boats.It was extremely difficult because the models of these boats were unparalleled. As mentioned above, the ostrich was widely used on boat decorationsdue to its religious and worldly importance, as mentioned above.

The representation of papyrus stems and sticks on some boats is a new style of decoration that was not common in that period. The diversity and difference in depicting the fronts and sterns of the boats of Tell Awlad Dawood, whether they are portrayed in the form of animals or birds, as well as the decorative elements above the boats and the nature of their use makes us assume that they are unconventional boats.

The boats of Tell Awlad Dawood are dated to Naqada IID2, or the Beginning of Naqada III A-B at the latest, from Late Chalcolithic to Proto-Dynastic period (3600- 3300 $\mathrm{BC})$.

\section{HOW TO CITE}

Nassef, A. \& Abd El-Krim, E. « Six Unusual Boats from Tell Awlad Dawood in the Nile Delta ", Journal of the General Union of Arab Archaeologists, vol. 6/2, 2021.

Doi: 10.21608/JGUAA2.2021.52837.1041

ahmedsaidn@gmail.com ; ehabgamil2013@yahoo.com

${ }^{49}$ FinKENSTAEDT 1979: 51-59. 


\section{SIX UNUSUAL BOATS FROM TELL AWLAD DAWOOD IN THE NILE DELTA}

\section{BIBLIOGRAPHY}

${ }^{\mathrm{c}}$ ABDEL AZIZ, S.: The Civilization of Ancient Egypt and Its Monuments, Part 1, Cairo (The Anglo Egyptian Bookshop) 1992.

'ALAADDIN, SH.: «The Ostrich Bird in Some Civilizations of the Ancient Near East», AJH 18, 2000, 8-41. DOI: 10.34120/0117-018-069-001.

ALEYDIS, VAN DE.: «Sacred and Secular: Ancient Egyptian Ships and Boats» (Book Review), AJA 111/4, 2007, 1-4. DOI: 10.3764/ajaonline1114.VandeMoortel.

ARVID, G. \& WALTER, W.: Schiffsmodelle im Alten Ägypten, Wiesbaden (Harrassowitz Verlag) 1971.

AYMAN, H.: «Hedgehog in Ancient Egypt», A Study on the Antiquities of the Arab World 12, 2010, 165-197. DOI: 10.21608/CGUAA.2010.35992.

BARBARA, A. \& CIALOWICZ, K.: Protodynastic Egypt, Buckinghamshire (Shire Publications)1997.

BJÖRN, L.: Ships of the Pharaohs: 4000 Years of Egyptian Shipbuilding, London (Allen and Unwin) 1970.

CIAŁOWICZ, K.: «Excavations of the Western Kom at Tell el-Farkha in 2006», RANS 1, 2009, 429455.

DINA, E.: «Ostrich Eggs of Predynastic Egypt», JGUAA 11, 2010, 40-56. DOI: 10.21608/JGUAA.2010.2754.

EHAB, G. \& AHMED, S. \& ETHAR, S.: Excavation at Tell Awlad Dawood, Season 1997, (Under Publication).

ELIZABETH, F.: «Egyptian Ivory Tusks and Tubes», ZÄS 106, 1979, 51-59.

FRANCIS, L.: Predynastic \& Pharaonic era Rock-Art in Egypt's Central Eastern Desert: Distribution, Dating \& Interpretation, Ph.D. Thesis, (Durham University) 2012.

GARDINER, A.: Egyptian Grammar, 3'rd (ed.), London (Oxford University Press) 1994.

GEORGE, R.: Models of Ships and Boats, Le Caire ( Institut Franc,ais d'Archéologie Orientale) 1913.

$\therefore$ «The Dog Which Was Honored by the King of Upper and Lower Egypt», BMFA 34 no.206, 1936. 96-99.

GREGORY, G.: Prehistoric Expeditions on the Nile: Boat Depictions on Prehistoric Egyptian Pottery, MA Thesis, Sydney (Macquarie University) 1998.

.: Ancient Egyptian Sea Power and the Origin of Maritime Forces, Sea Power CentreAustralia (Sea Power Centre Australia) 2008.

HALA, M.: Symbols of the Sacred Animals and Birds in Boats of the Ancient Egyptian Civilization until the End of the New Kingdom, MA Thesis, Faculty of Arts - cAin Shams University, 2015.

HAMED, H.: The Scientific Report of the Excavations of Tell Awlad Dawood, Season 1982, Sharqiya Antiquities Region, (Unpublished).

HENDRICKX, S.: The Relative Chronology of the Naqada Culture, (Unpublished Text Deliveredat the British Museum Colloquiumon ,Early Egypt', London, 22 July 1993, 1993.

HOSNI, A.: «The Boats in the PreDynastic», JSA 3, 2011, 19-52. DOI: 10.33948/1643-000-003-001.

IBRAHIM, H.: A Study of the History of Egyptian Boats and their Stages of Development from the Dawnof History until the End of the Old Kingdom, MA Thesis (Alexandria University), 1984. 


\section{Ahmed Said Nassef \& Ehab Gamil Abd El-Krim}

IBRAHIM, S.: The Scientific Report of the Excavations of Tell Awlad Dawood, Season 1993, Sharqiya Antiquities Region, (Unpublished).

KROEPER, K.: Minshat Abu Omar I. Ein vor- und Frühgeschichtlicher Friedhof im Nildelta. Gräber 1-114, Mainz (Verlag Philipp von Zabern) 1994.

LIONEL, C.: Ships and Seafaring in Ancient Times, British Museum Press, London (British Museum Press) 1994.

.: Ships and Seamanship in the Ancient World, Published by Johns Hopkins University Press, London (Johns Hopkins University Press) 1995.

LUC, W.: «Copper Drops and Buried Buildings: Ma'adi's Legacy as a Predynastic Delta Trade Capital», Bul. Soc. Geog. Egypte 73, 2000, 163-184.

MAHMOUD, Y.: The Scientific Report of the Excavations of Tell Awlad Dawood, Season 1989, Sharqiya Antiquities Region, (Unpublished).

MICHAEL, H.: Egypt before the Pharaohs, New York (Alfred A. Knopf) 1979.

MOHSEN, H. \& NASSIF, A.: The Scientific Report of the Excavations of Tell Awlad Dawood, Season 1997, Sharqiya Antiquities Region, (Unpublished).

NAGY, M.: The Scientific Report of the Excavations of Tell Awlad Dawood, Season 1990, Sharqiya Antiquities Region, (Unpublished).

OSAMA, B.: The Military Fleet in Ancient Egypt from the First Intermediate Period until the end of the Ptolemaic Period (Archaeological Study), MA Thesis, Department of Archeology - Faculty of Arts (Tanta University) 2016.

PETRIE, W.M.: Egyptian Shipping, in Ancient Egypt and the East, Macmillan: British School of Archaeology in Egypt, Londres (British school of archaeology in Egypt) 1933.

RADWAN, A.: Ein Jenseitsboot der 1. Dynastie aus Abusir-Teil I, In Eva-Maria Engel, Vera Müller, and Ulrich Hartung (eds.), Zeichen aus dem Sand: Streiflichter aus Ägyptens Geschichte zu Ehren von Günter Dreyer, 559-571. Wiesbaden (Harrassowitz Verlag) 2008.

REINHOLD, E.: Die Felsgravierungen im Distrikt Sayala-Nubien, Oesterreichisch, Akademie der Wissenschaften Philosophisch- Historische klasse Denkschriften 90, Wien (Hermann Böhlaus Nachf. : Kommissionsverlag der Österreichischen Akademie der Wissenschaften) 1965.

SAID, A.: The Scientific Report of the Excavations of Tell Awlad Dawood, Season 1978, Sharqiya Antiquities Region, (Unpublished).

SAMAR, M.: «A Study on Portraying Hunting Dogs in the Old Kingdom», JAAUTH 16, 2019, 9099. DOI: 10.21608/JAAUTH.2019.57490.

SEÁN, M.: Boats of the World: From the Stone Age to Medieval Times, Oxford (Oxford University Press) 2004.

STAN, H.: «Late Predynastic Falcons on a Boat (Brussels E.7067) », JSAS 24, 2008, 371-384.

STEPHEN, V.: Boats of Egypt before the Old Kingdom, Master of Arts, (University of Texas at Austin) 1987.

: Egyptian Boats and Ships, Shire Egyptology (Princes Risborough) 1994.

: Egyptian Boats and Ships, Shire Egyptology (Paperback) 2008.

: «Boat (Use of)», UEE 1/1, 2013, 1-13.

TARIQ, H.: The Scientific Report of the Excavations of Tell Awlad Dawood, Season 1991/1992, Sharqiya Antiquities Region, (Unpublished).

TATIANA, SH.: Seven Baboons in One Boat. The Iconography of the Tell Ibrahim Awad Temple Cult, in: 


\section{SIX UNUSUAL BOATS FROM TELL AWLAD DAWOOD IN THE NILE DELTA}

Egyptology at the Dawn of the Twenty-first Century, Cairo (American University in Cairo Press) 2002.

: Seven Baboons in One Boat: The Interpretation of Iconography in the Context of the Cult Belonging to the Temple at Tell Ibrahim Awad, Cairo (American University in Cairo Press) 2003.

VAN HAARLEM, W.: «A Remarkable 'Hedgehog-Ship' from Tell Ibrahim Awad», JEA 82, 1996, 197-198.

$\therefore$ Temple Deposits in Early Dynastic Egypt: the case of Tell Ibrahim Awad, (Leiden University) 2014.

VANDIER, J.: Manuel d'Archéologie Égyptienne,I, Paris (Éditions A. et J. Picard et Cie) 1952.

VANHULLE, D.: «Boat Symbolism in Predynastic and Early Dynastic Egypt: An EthnoArchaeological Approach», JAEI 17, 2018, 173-187.

VENICE, I.: Ostriches in Ancient Egypt (Pharaonic \& Coptic epochs) V I S, January, 2018, 1-28.

WARD, CH A.: Sacred and Secular: Ancient Egyptian Ships and Boats, Philadelphia (Published for Archaeological Institute of America, Boston, MA by The University Museum, University of Pennsylvania ; Dubuque, Iowa : Kendall/Hunt publishing company) 2000a.

: The Late Period Boat at Mataria, Cairo: Breaking with Tradition, MA, Boston (Archaeological Institute of America) 2000b.

WILFRIED, S.: Ägypten Götter, Gräber und die Kunst - 4000 Jahre Jenseitsgeschichte, Band I, Linz (OÖ. Landesmuseum) 1989.

WINKLER, H.: Rock Drawings of Southern Upper Egypt, Vol. 1, EES, London (Egypt Exploration Fund) 1938. 


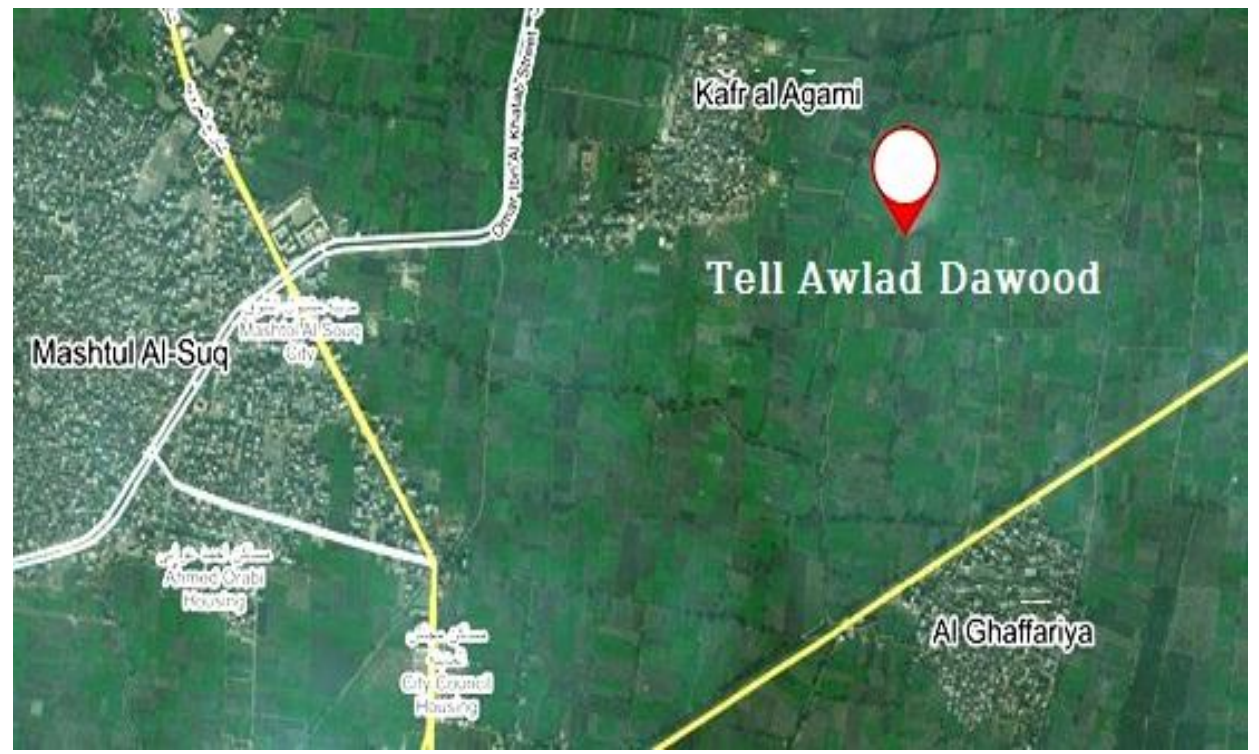

[FIGURE 1]: A map showing the location of Tell Awlad Dawood.

Google Earth

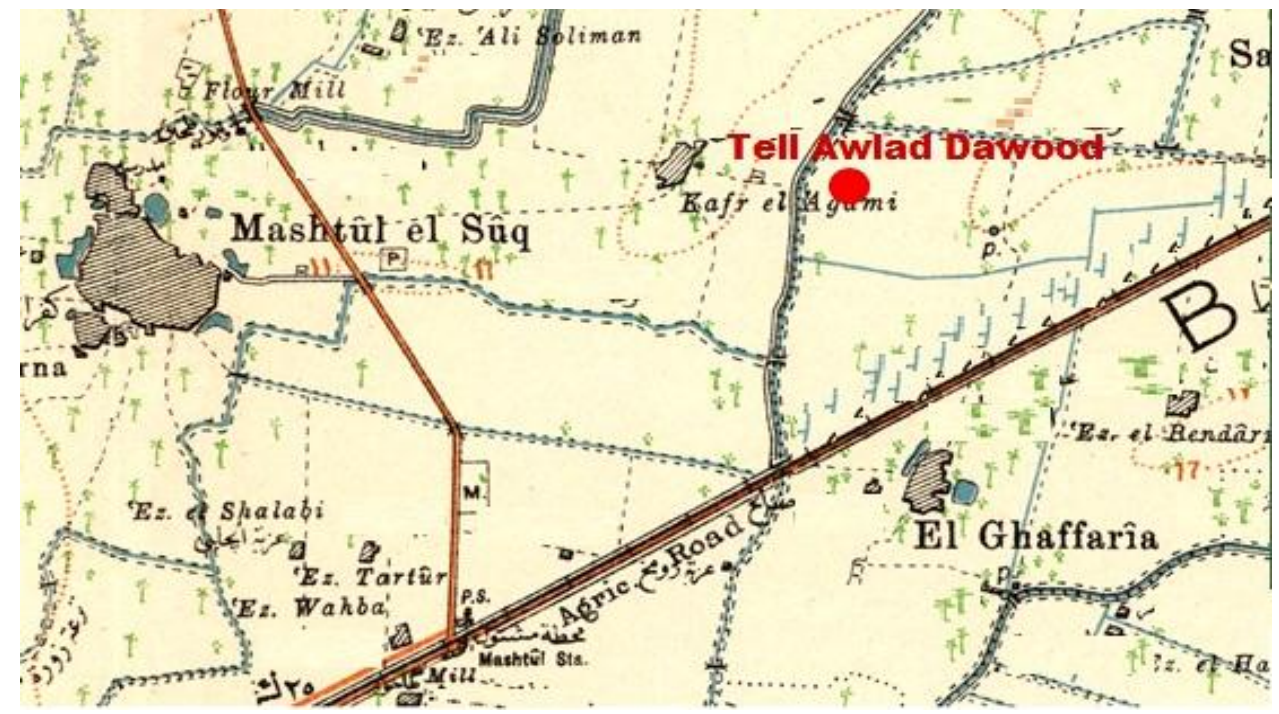

[FIGURE 2]: Tell Awlad Dawood location: Map of Shebin El Kanater, printed 1916, Scanned 1907 (Atlas of Egypt, scale 1: 50000) 


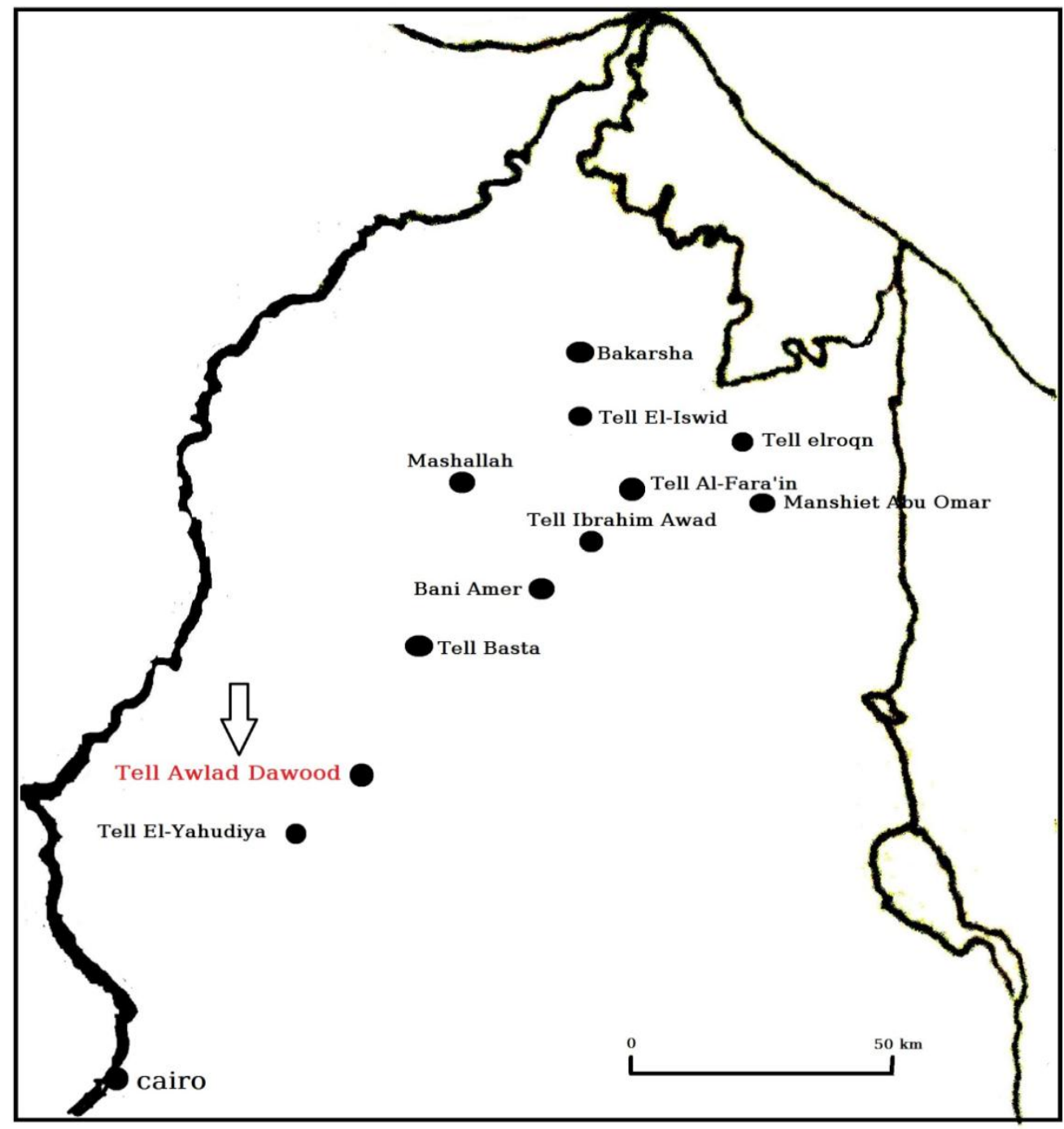

[FIGURE 3]: A map showing Tell Awlad Dawood location Drawing by Ehab Gamil according to: Atlas of Egypt scale 1/25000 edition. 1947 


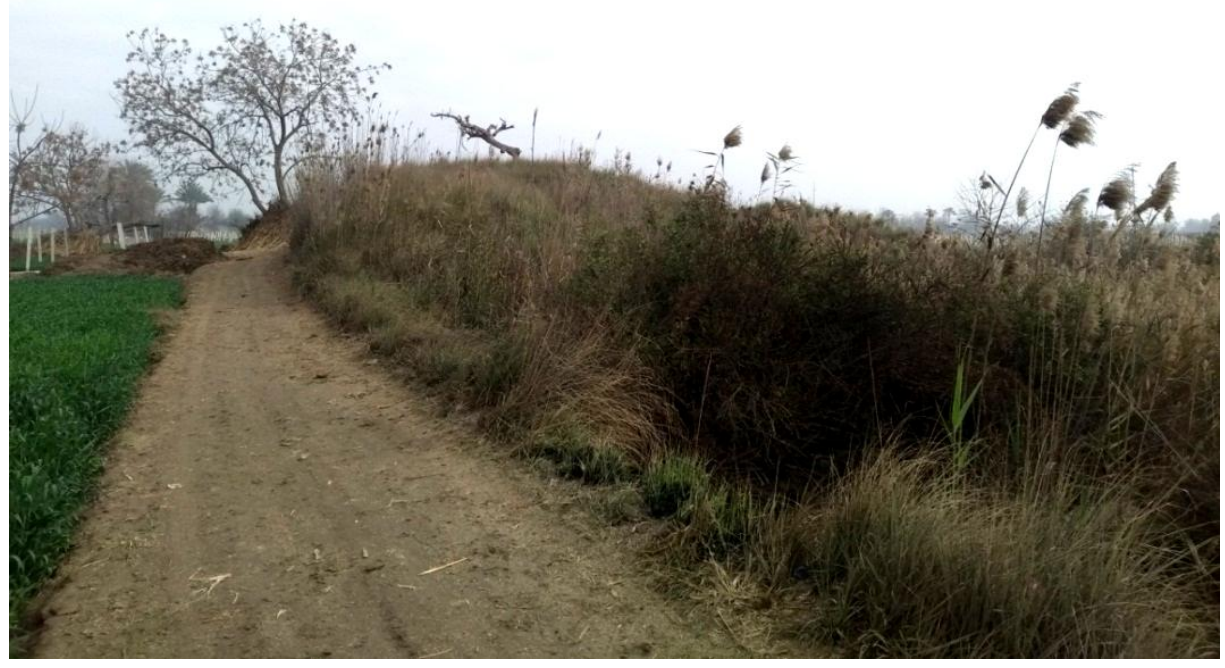

[FIGURE 4]: A view of the Tell.

(C)Photo by The authors 6. Feb. 2021

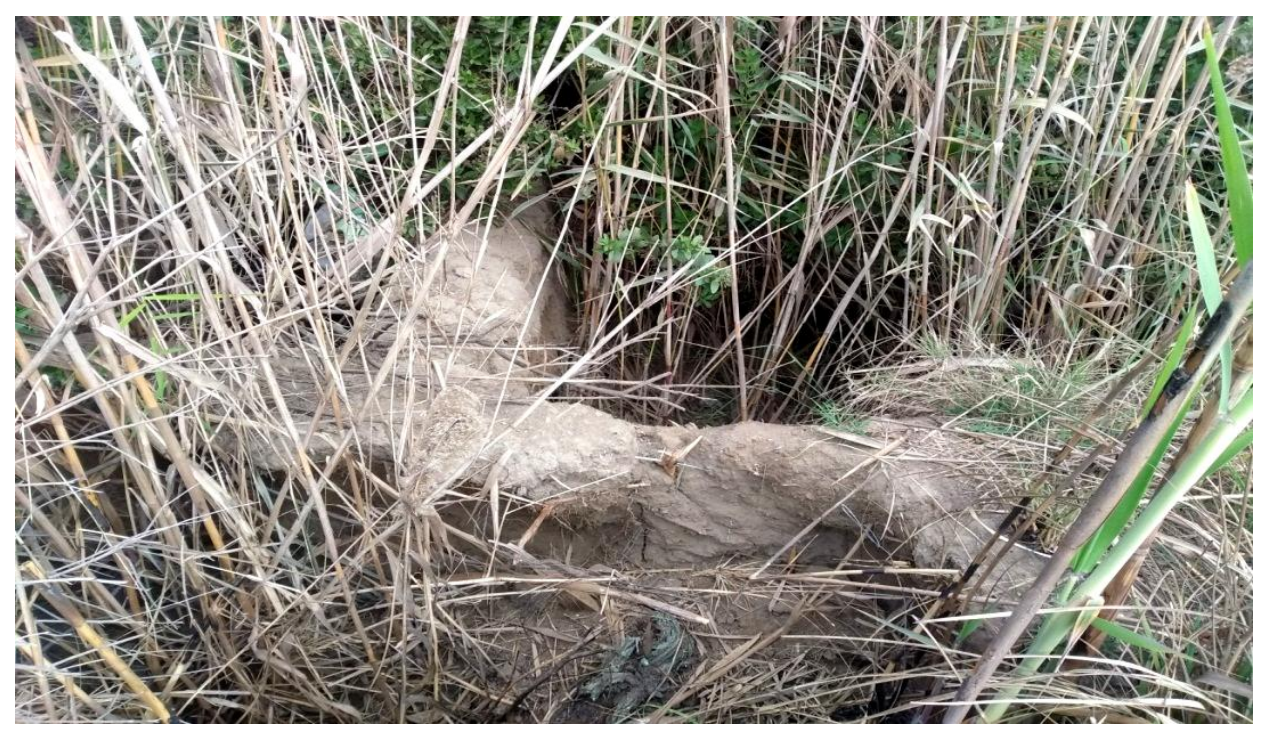

[FIGURE 5]: The remains of walls covered with halfa grass.

CPhoto by The authors 6. Feb. 2021 

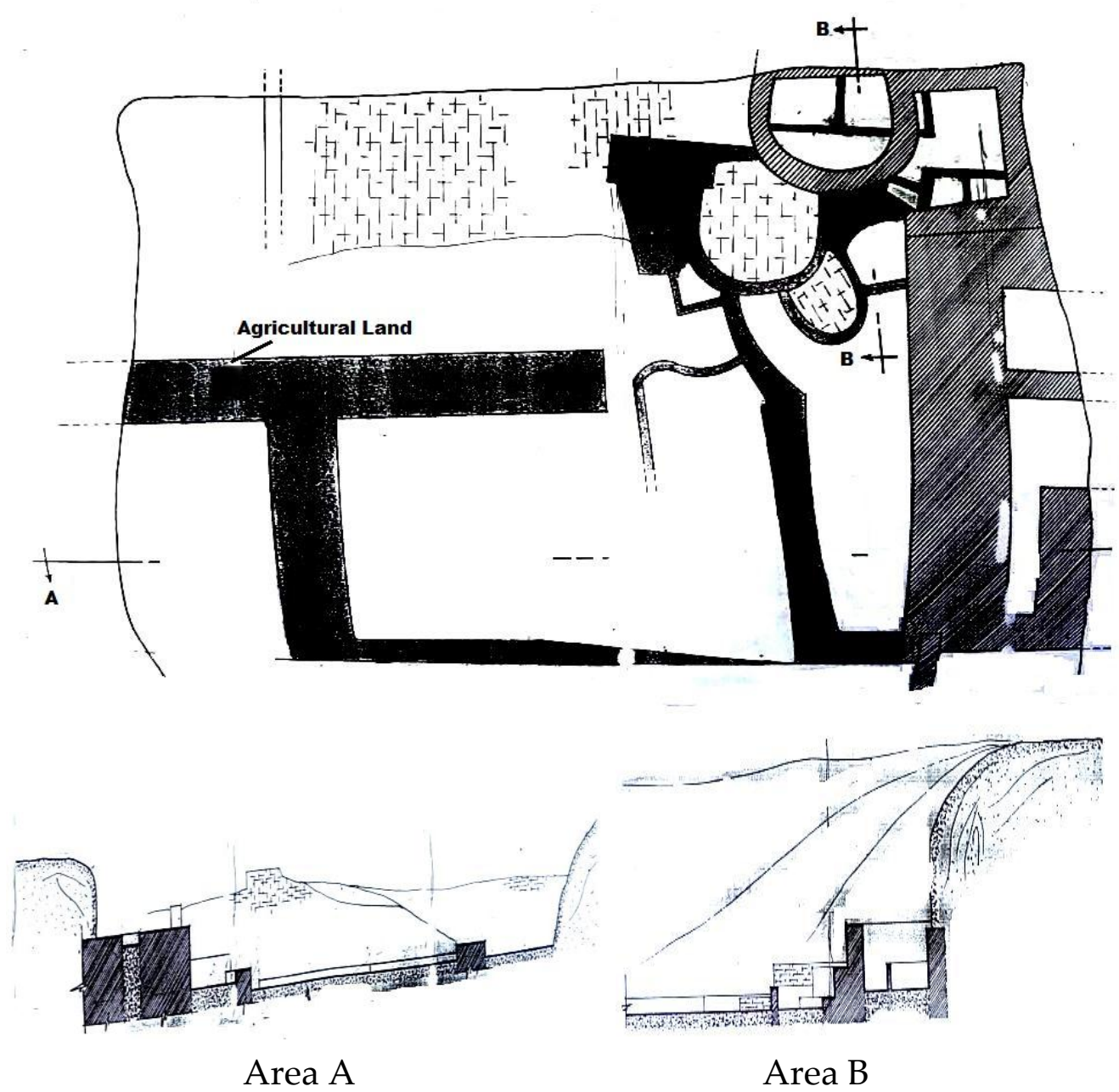

[FIGURE 6]: Topographical map showing the areas excavated in 1997 where the boats were found scale 1/50 (Mohsen 1997, 12-13, FIGS.1-2
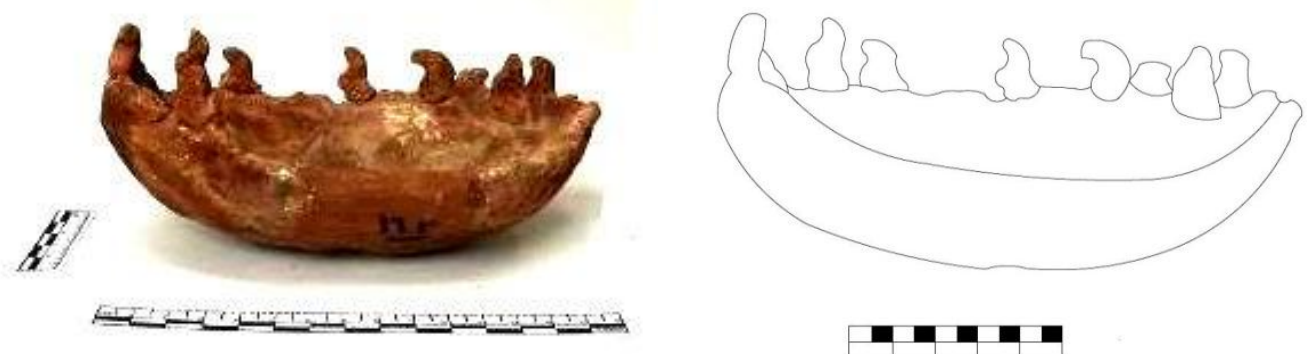

[FIGURE 7]: The first boat [GEM. №. 67656]

(P) Photo by Ehab Gamil- drawing by Ahmed Said. 


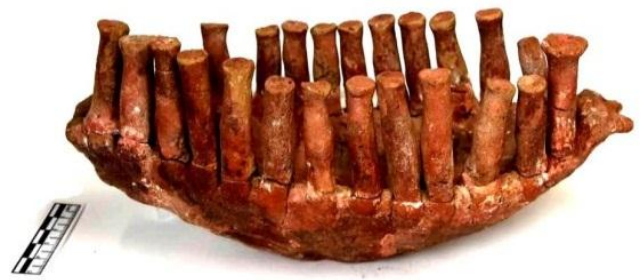

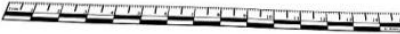

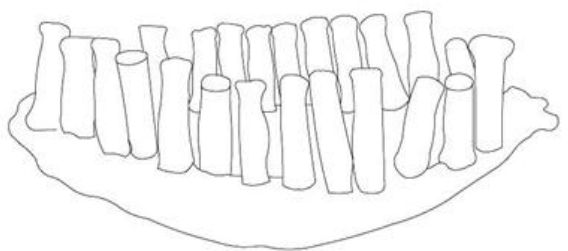

뭄ำ

[FIGURE 8]: The second boat [GEM. №. 67657]

(CPhoto by Ehab Gamil- drawing by Ahmed Said.
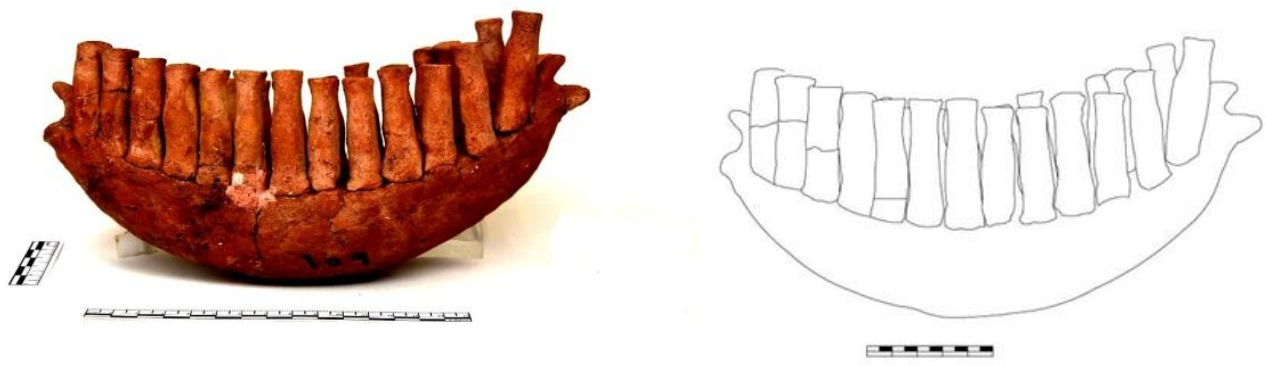

[FIGURE 9]:. The third boat [GEM. №. 67658]

(Photo by Ehab Gamil- drawing by Ahmed Said.
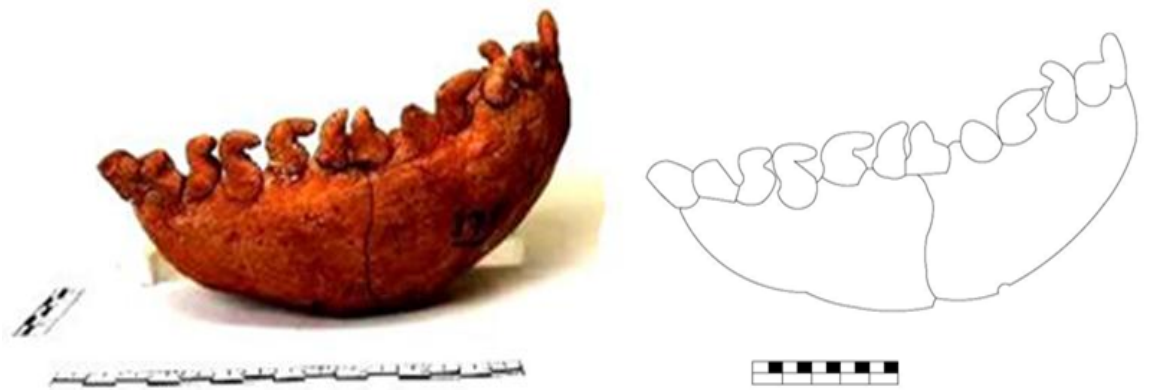

[FIGURE 10]: The Forth boat (GEM. №. 67659)

(P) Photo by Ehab Gamil- drawing by Ahmed Said.
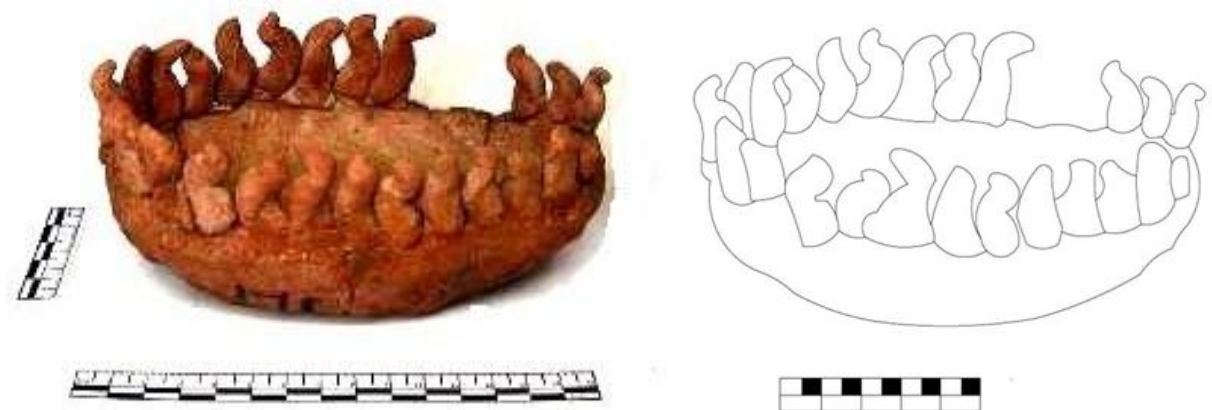

[FIGURE 11]: The fifth boat [GEM. №. 67660]

(OPhoto by Ehab Gamil- drawing by Ahmed Said. 

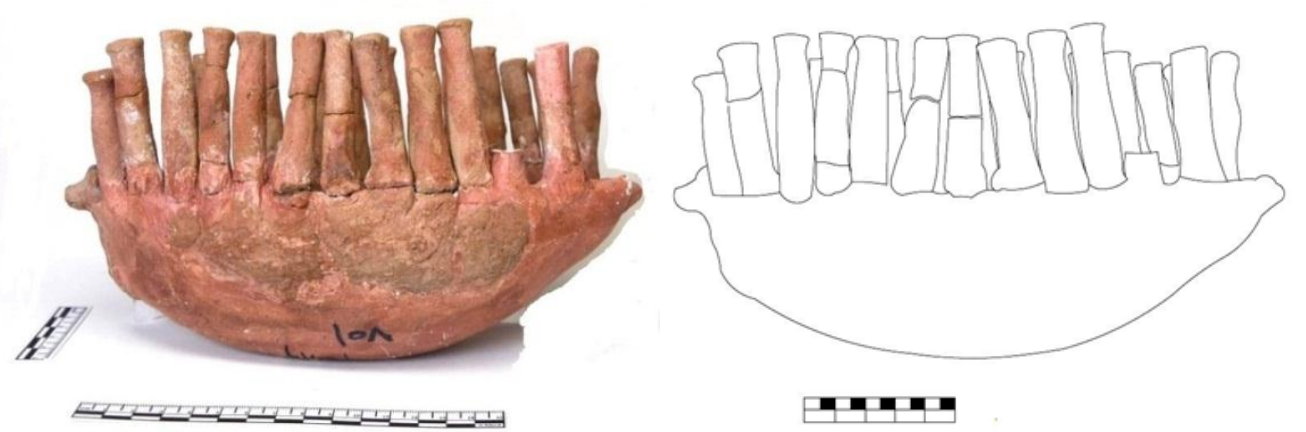

[FIGURE 12]: The sixth boat [GEM. No. 67661]

CPhoto by Ehab Gamil- drawing by Ahmed Said.

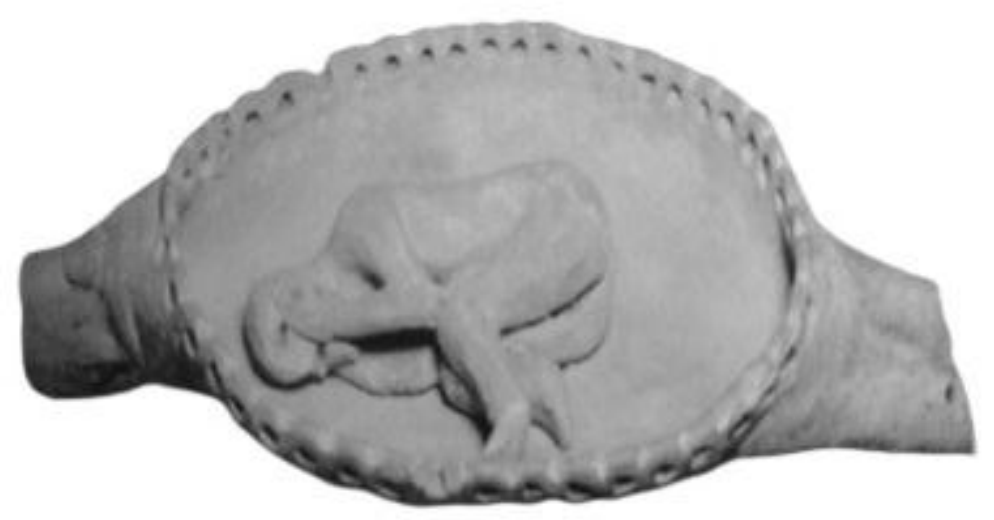

[FIGURE 13]: A boat from Naqada I Inv. Nr. F 1962/12.1 SEIPEL 1989, 43, №.8.

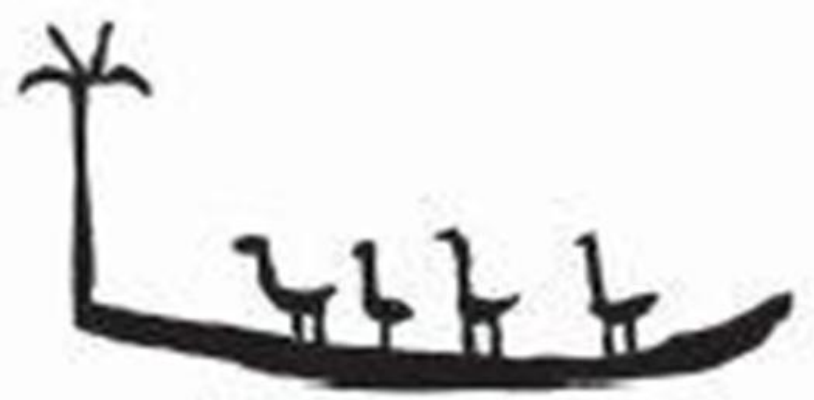

[FIGURE 14]: Ostrich on a boat, FRANCIS 2012: 135.

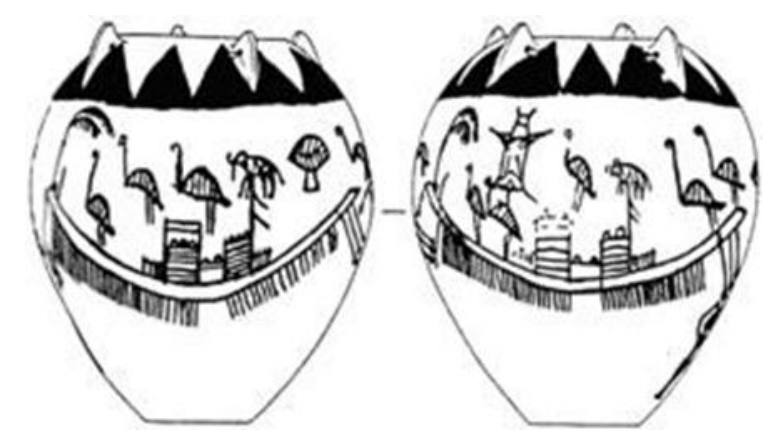

[FIGURE 15]: the appearance of ostriches with a boat on a vase from Naqada II in Ashmolean Museum of Art and Archaeology AM 1895. 584

PAYNE 1993: FIGS. 42: 86 

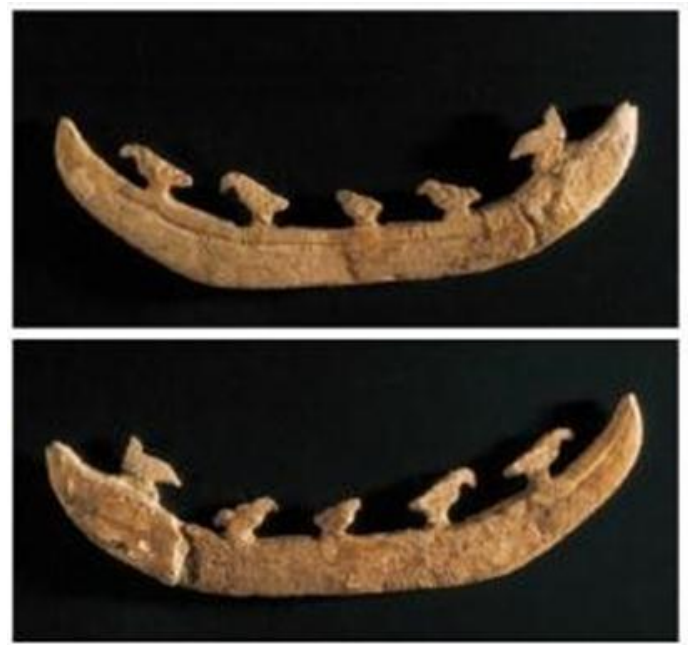

[FIGURE 16]: Falcons with an ostrich at the end of the birds, model boat in the Brussels Museum E7067 HENDRICKX 2008: PL. I.1.)

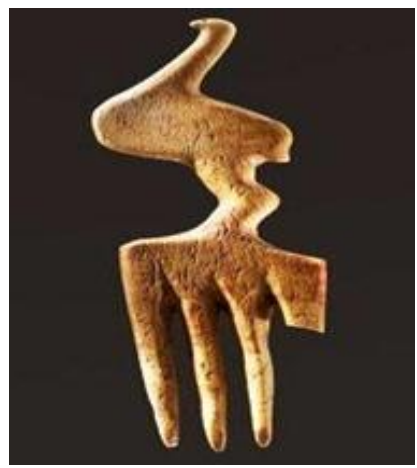

[FIGURE 17]: An ostrich shaped comb, made of bone, dating back to late Naqada I- Naqada II 39003500 BC. the Metropolitan Museum VENICE 2018: 15.

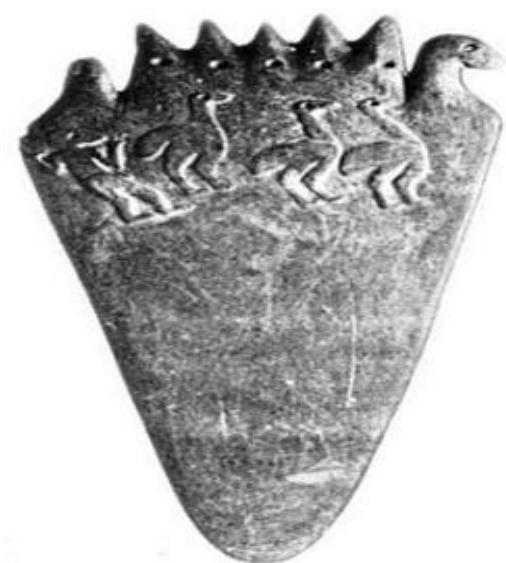

[FIGURE 18]: Manchester palette, man driving three ostriches, Naqada II VANIER 1952: 572, FIG. 379. 


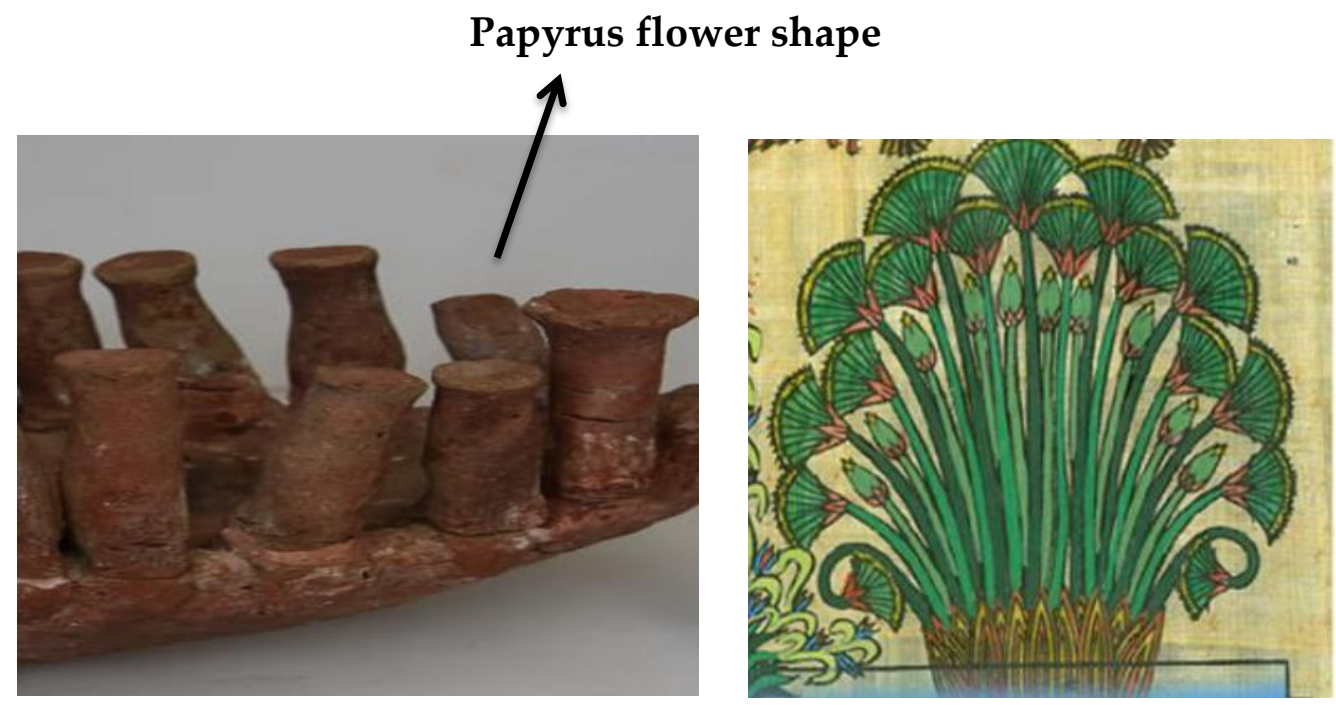

[FIGURE 19]: The pillars in one of the boats of Tell Awlad Dawood Http://www.google.com.eg/imgres?imgurl , http://www.aregy.com/forums/ArchaeologyGgodKSQEPA
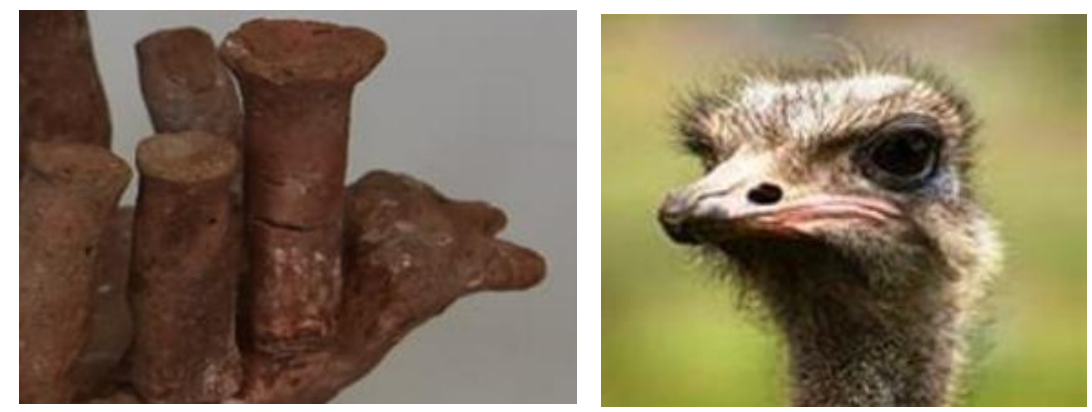

[FIGURE 20]: Ostrich head shape and Front of the second boat

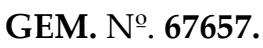

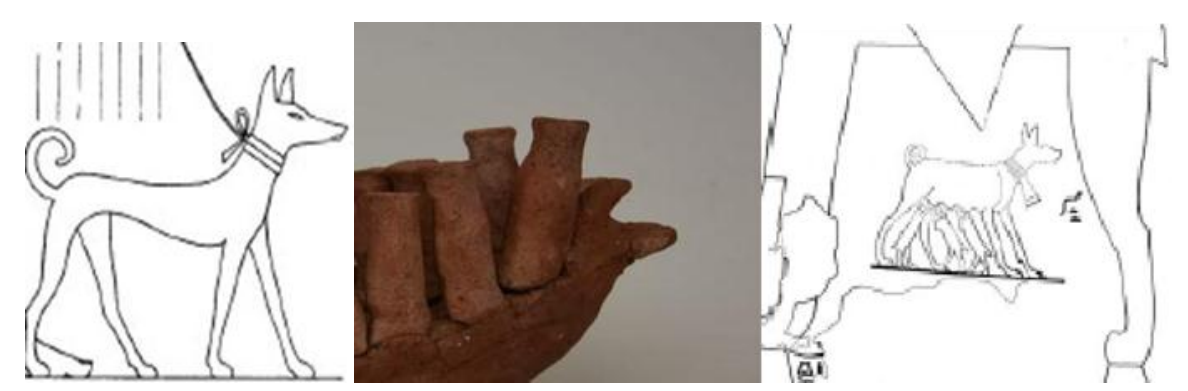

[FIGURE 21]: Comparing the head of a dog with a boat of Tell Awlad Dawood (GEM. №. 67658) REISNER 1936: 97-99. 


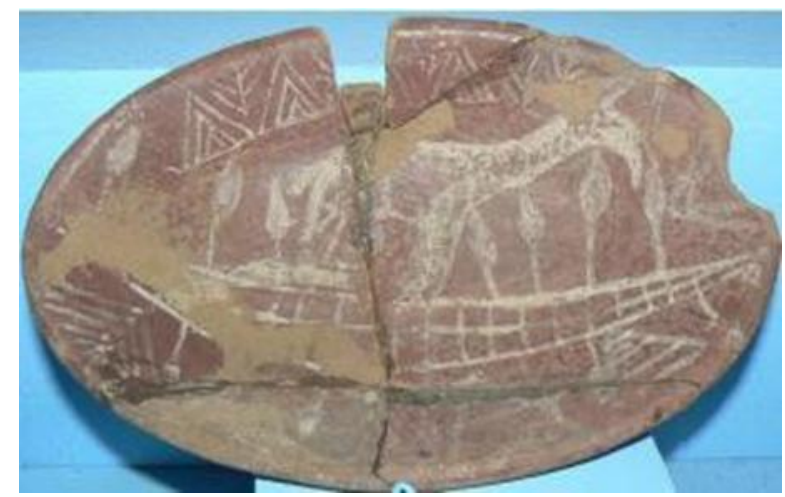

[FIGURE 22]: A boat with a dog depicted on a plate Naqada I Egyptian Museum CG5877

HALA 2015: 258.

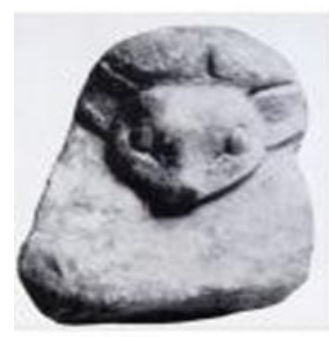

(A)

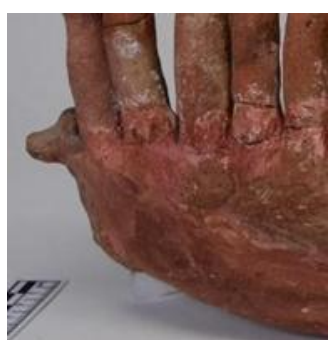

(B)

[FIGURE 23]: (A) a hedgehog's head piece in the Stockholm Museum, Hala 2015: 258, (B) Tell Awlad Dawood boat [GEM. №. 67661]
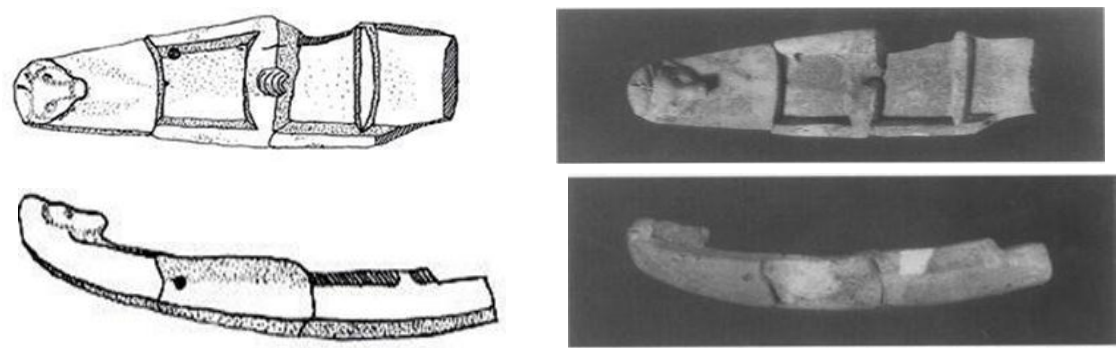

[FIGURE 24]: Model boat in the form of a hedgehog from Tell Ibrahim Awad VAN HAARLEM, 1996: 198. 


\title{
ستة قوارب غير تقليدية من تل أولاد داوود فى دلتا النيل
}

\author{
أحمد سعيد ناصف وإيهاب جميل عبد الكريم \\ مدرسون بكلية الاداب -جامعة بنها
}

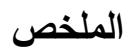

تل أولاد داوود واحدًا من المواقع الهامة فى محافظة الثرقية، وهو عبارة عن مستوطنة ترجع إلى عصر ما قبل الأسرات وأوائل الأسرات، وهو تل صغير تن استيطانه بداية من الألفة الرابعة قبل المبلاد وحتى العصر المتأخر، لكن الاسنيطان

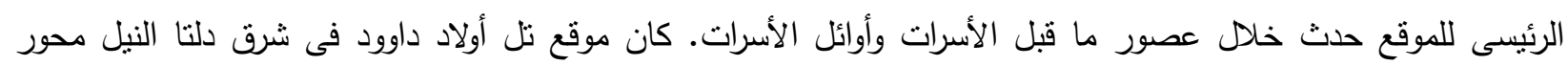

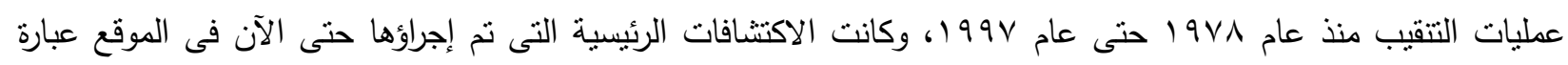

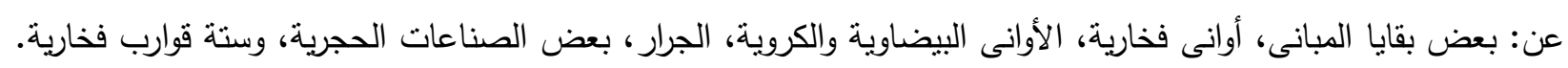

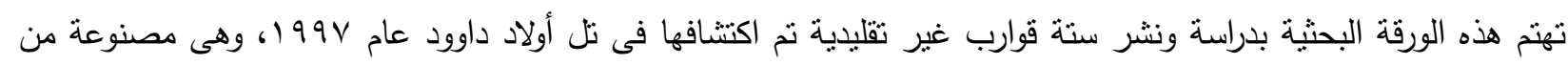

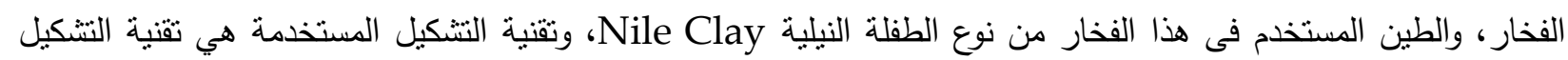

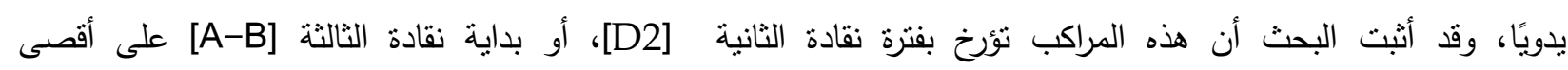

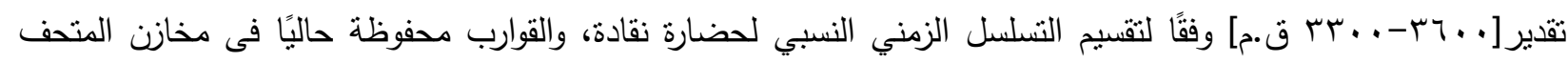
المصري الكبير فى القاهرة.
\end{abstract}

الكلمات الدالة: قوارب، تل اولاد داوود، نقادة الثالثة، ما قبل الأسرات، فخار، ودائع الأساس. 